\title{
A SPATIAL DIALOGUE OF HERITAGE VILLAGE BETWEEN KAUMAN IN SEMARANG AND SEOCHON IN SEOUL TOWARD PRESERVATION DEVELOPMENT
}

\author{
Atiek SUPRAPTI ${ }^{1 *}$, Saehoon $\mathrm{KIM}^{2}$, Edward E. PANDELAKI ${ }^{1}$, Satriya W. FIRMANDHANI ${ }^{1}$ \\ ${ }^{1}$ Architecture Department, Faculty of Engineering, Diponegoro University, Semarang, Indonesia \\ ${ }^{2}$ Department of Landscape Architecture, Urban Design Concentration, Graduate School of Environmental \\ Studies, Seoul National University, Seoul, Korea
}

Received 27 September 2017; accepted 26 February 2018

\begin{abstract}
Semarang is one of big cities in Indonesia contains of multy ethnics. They traditionally settled down inside a group of villages. Kauman is the cultural heritage of Muslim settlement in Semarang. The peculiarity of local Muslims in Java's coastline and the strong social cohesion colour the people's daily life. Seochon in Seoul is a historic area and the home for more than 670 hanoks. In 2008, Seoul Metropolitan Government issued a conservation plan and recruited a team of architects and academics to observe and investigate Seochon's condition and discover the possibilities of conservation there. It turned out that Seochon has a great potential for revitalization. Nowadays, Seochon has become a tourism destination having both traditional and contemporary cultural value. This research aims to understand the efforts of preservation done by the government and public participation for the sake of preservation. This research used primary and secondary data and comparative study methods. Seochon village has been successful in developing preservation and preservation placed as the best example. The result of research showed that the conservation and preservation of Kauman needs a workable rules to manage and investigate the potential and resources. The result of this research could be used to any other cases similar to Kauman.
\end{abstract}

Keywords: preservation, cultural heritage, village, spatial, dialogue, architecture, planning.

\section{Introduction}

Taking care of the indigenous cultural heritage will strengthen local identity. Local identity is an important socio-cultural capital to be able to contribute in the globalization market (Hanru, 2012; Santoso, 2013). The advantages of maintaining cultural heritage include to strengthen the character of the city and provide knowledge for the younger generation. The local socio-cultural wealth also can be an attractive asset for tourism purposes (Rypkema, 2005).

Semarang, Indonesia and Seoul, South Korea hold a lot of urban village heritage that has significantly influence the formation of their local identity. The problems of urban village heritage include: degradation, history, urbanization, infrastructures, economy and capital, developed in accordance with their environmental conditions and situations.

Kauman village, one of the fillers of the settlement mosaic in Semarang, is one of Semarang's historical assets. The embryo of this traditional settlement was started in the 17th century. Kauman is known as the settlement of devoted Muslims. The character of this village is apparent from the strong social ties, which started from the kinship of Kyai (religious leaders). People's economic activities have developed alongside the main corridor and been absorbed into the settlement inside the village. Here, old buildings with distinct cultural heritage architecture style are easy to find. One of the historical buildings protected by preservation policies is Masjid Agung (Grand Mosque). Cultural-religious activities of Muslims in Java's northern coastline invite many local tourists. One of the most famous celebrations is the annual Dugderan festival, a fair welcoming Ramadhan month (the month of fasting). Preservation effort is spontaneously done by the people, and it competes with changes associated with modernization-capitalization (Suprapti, Kistanto, Pandelaki, \& Indrosaptono, 2017).

*Corresponding author. E-mail: atiekbudiarto@gmail.com 
Seochon is a residential district located in the center of Seoul. It is next to the Gyeongbok Palace. It has stood for more than five centuries. It hosts approximately 670 traditional Korean houses that called hanoks, and a large number of them remain in good condition. Some hanoks have been transformed into nonresidential uses, away from their original state. The community, alongside with the government, especially towards the buildings and the environment (Kwon, Kim, \& Jeon, 2014), systematically does preservation acts. New and modern buildings are also constructed to liven up the area. As a heritage villages Kauman and Seochon each has its own distinctive characteristic, Kauman is an egalitarian religious village, while Seochon is an intellectualist and artist village. However both of village are a place to live for common people. Both of them has experience in heyday and period of decline. Seochon experienced heyday in the period of Joseon dynasty then the decline period was in the Japanese occupation period, at this moment it gets pressure from modernization capitalization of city centre. The same condition has experienced by Kauman, it got a significant development in the period of Mataram Sultanate because its location coincide to the Kanjengan palace as a centre of district government. Both of Kauman and Seochon are an ancient village which are store of many traditional buildings. Seochon keeps a lot of hanok, while Kauman has the various potential old building such kind of: vernacular Javanese buildings (omah), indische, art deco, and jengki. At this time Seochon's success in conserving its local cultural heritage and packaging it into a tourism asset by incorporating public participation is an invaluable field practice. The unique environment of Seochon nowadays has become one of the most visited cultural sites and tourism places in Seoul. Meanwhile, Kauman is still searching for the right formulation of the preservation efforts. Kauman and Seochon have many similarities in terms of possessing tangible and intangible culture. Both heritages are also complemented with the traditional social life of the people, and they are experiencing pressure from modernization and capitalization surrounding them. Both areas also have great demand for public participation before or during the development. This article will reveal the importance of community participation in the preservation of cultural heritage village. The research's objective is to learn the success of Seochon preservation development that can be provide an important reference towards the preservation development of Kauman.

\section{Methods}

This study uses comparative study method with the combination of qualitative rationalistic. Comparative method is intended to understand the cause and effect of the preservation issues in Kauman by comparing it with Seochon, Seoul as the best practice. Meanwhile, the qualitative ra- tionalistic is intended to give a precise analysis. Rising from a holistic research of a grand concept, observation in a specific object and the result is seated into the grand concept in order to build a major theory (Muhadjirin, 2007). Data collection is done through secondary and primary data collection, through questionnaires, interviews, documentation, and field observation. Secondary data includes: government policies regarding to the preservation effort, government policies regarding to tourism, and previous studies. Primary data includes: socio-cultural condition of the people, condition of the spatial artefacts and the cultural heritage buildings, and public participation regarding to the preservation. Result and Analysis use qualitative logic and verbal analysis in Kauman and Seochon. The meaning of the analysis expands the empirical truth for the sensual empirics. Result and analysis is an imagery of the potentials in public participation, socio-culture, spatial architecture, and government policy. Comparative analysis is done after the previous step by analyzing the connection of cause and effect in the case of Kauman by studying Seochon. Thus, an answer for why the preservation effort is far less successful in Kauman will emerge. The village is located at the administrative district of Central Semarang and divided into two Kelurahan (the smallest administrative area) namely Kelurahan Bangunharjo, which consists of $R W$-I (name of group of neighborhood association) and $R W$-II, and Kelurahan Kauman (RW-I, RW-II, and RW-III) (Suprapti, Budihardjo, Kistanto, \& Tungka, 2010).

\section{Result \& discussion}

\section{Result}

Kauman village has a distinctive character, the value of "Kauman". This means Kauman nature includes the clerical blood affinity, obedient to the teachings of Islam, most people are hajj, and live in the villages around the city's Masjid Agung (Suprapti et al., 2010; Suprapti, 2016). Public participation appears prominently in a strong social cohesion. It is apparent from: 1) the activities of community in constructing building / land for religious activities; 2) the roles of community in socio-cultural activities; 3 ) the roles of community in protecting themselves against cultural influx from outside; 4) community participations in religious education. However, such participation not yet focused on preservation activities on the potential of cultural heritage. It is necessary for the establishment of a network of participation activities, as well as community empowerment at $R T, R W$, community leaders, and cooperation with other parties interested in cultural heritage (Wirastari \& Suprihardjo, 2012).

The land use of Kauman village consists of allotment land for trade, worship, social facilities and housing. As the settlements are located at the centre of Semarang and immediately adjacent to Johar trading area, the presence of a very lively trade zone develops. This trade zone is centralized on the main corridor of Jl. Kauman (see Figure 1). 


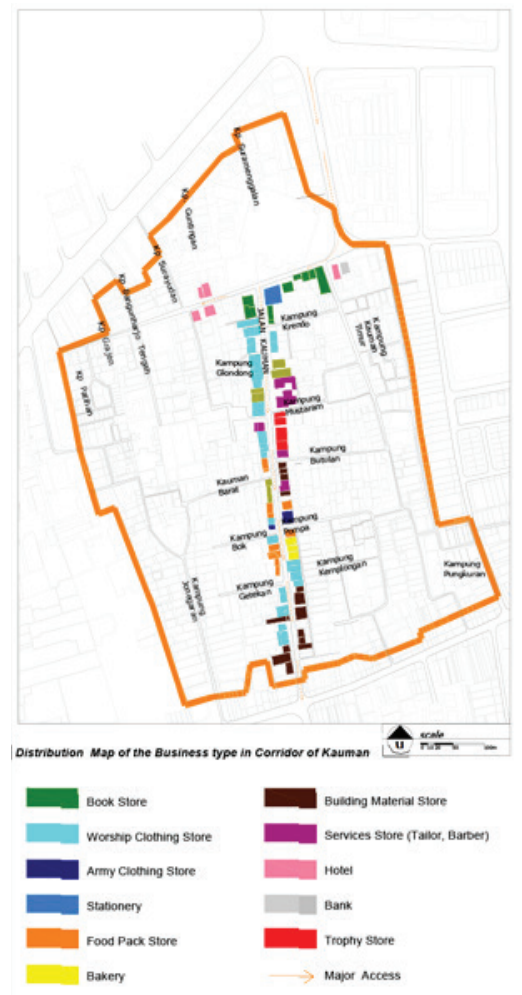

Figure 1. The spread of trading activity in the main corridor of Jl. Kauman

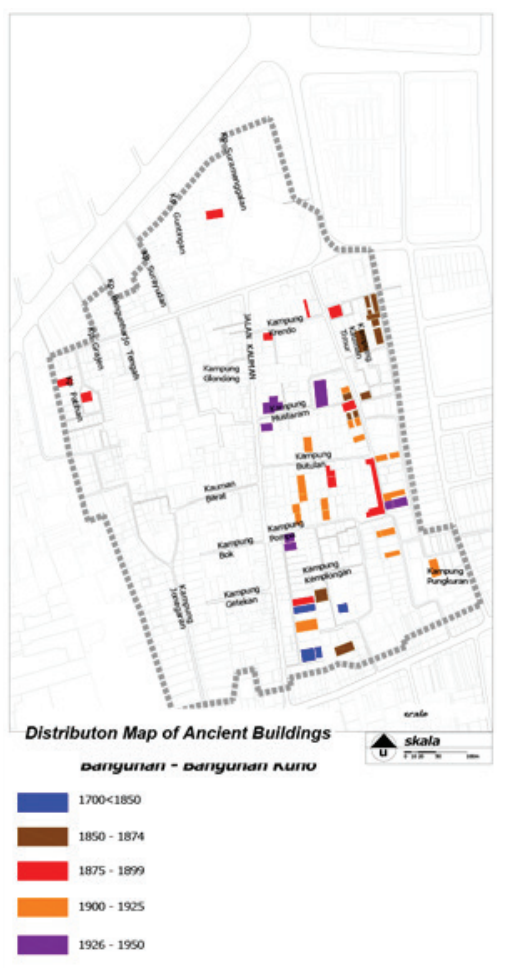

Figure 2. The spread of ancient houses which were built in 1800 s period

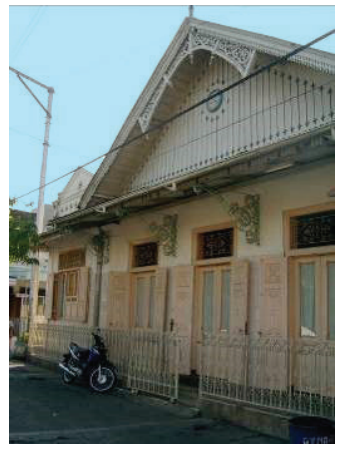

Figure 3. Appearance of Indische house style in Kauman

(source: author, 2016)

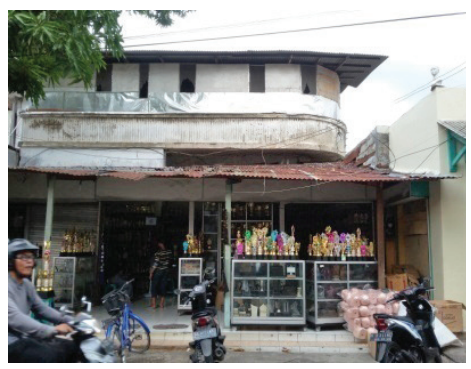

Figure 4. Art deco style, local people call it house boat (source: author, 2016)
Several buildings are categorized as ancient houses, which is spread all over the village (see Figure 2). The styles are indische (Figure 3) and modern art deco. The indische house appeared in the periode of $18^{\prime}$ th to 19 'th century, which is a mixture of Dutch and local architectural style (Beal, 2013). Figure 4 shows the existing condition of the houseboat as a reflection of Architectural art deco, which indicates that the preservation efforts are not going well. Indische style, with porch hallmark, supported classical pillars or iron poles, classical gable and cornice or fronton, and luipel corrugated, was popular in the 1800s (Leushuis, 2014). Art deco style developed in the early 1900s, which were characterized by forms of more linear geometric. The average building conditions are not good, and several buildings have been abandoned.

The other land uses are for worship facilities and social facilities. The public and social facilities in Kauman have the same properties and functions as the other settlements. In social facilities, there are some buildings such as school buildings, administration buildings (district office), and public toilets. However, there are no social facilities such as green open spaces functioning as a garden and water infiltration, and there are also no heritage values at these facilities.

The second land use of Kauman is the settlement area. It dominates the region of this area. It consists of many ancient houses of Javanese vernacular and jengki style (see Figure 5 \& 6). Java has its own vernacular, the way to adjust to the nature of the weather, and the local climate. In the areas of Central Java, particularly in Semarang, where rainfall is quite high and the temperature is warm, the Javanese vernacular is in the form of slant - roofed like joglo, pencu, pyramid, and gable with a square floor plan, many windows, and shaded by sun shading to avoid rainwater come into the house. Javanese vernacular is reflected in some of the houses.

The architectural jengki style is typical Indonesian style that appears to distinguish from the colonial architecture. Jengki style appeared in the era of 1950-1960, and all the buildings using jengki are still relatively young $( \pm 60$ 


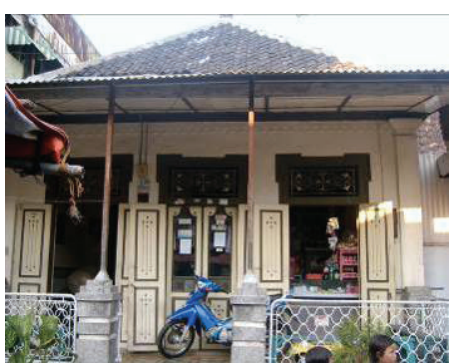

Figure 5. Javanese Vernacular style (source: author, 2016)

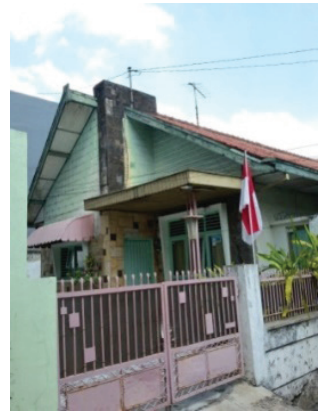

Figure 6. Jengki Style house (source: author, 2016) years) than the other ancient buildings. The existence of a very distinctive architecture jengki style can be seen from the gable that stands on one side.

Seochon (서촌, literally "West village") is one of the oldest neighborhoods in Seoul, South Korea. The area was traditionally associated with the early period of Joseon Dynasty. The name is associated with its location to the west of the Gyeongbok Palace, similar to Bukchon (북촌, literally "North village") which is located in the north of the city center. Seochon has many hanoks (traditional Korean houses), see Figure 7 and 8. In the late of 1960s, in Seoul, a number of newly constructed hanoks decreases to a few hundred or less per year (Kwon et al., 2014). In the late 1990s, the preservation of hanoks was begun to be associated with cultural assets and a potential attractions for tourism industry (Kwon et al., 2014; Jeon \& Kwon, 2012). Seochon in one of the districts in which the preservation policy of hanoks was implemented. Some of hanoks in Seochon are clustered in a series of connected alleys, while others are scattered across the neighborhood, often in the middle of modernized buildings. Most of the alleys with clustered hanoks are small and winds like a maze (Figure 9). During the Joseon period (1329-1910), the Seochon citizens were often called 'wihangin'. Wihangin were also called 'jungin', which literally means the middle-class people who are neither noblemen nor commoner like interpreters, doctors, lawyers, and mer-
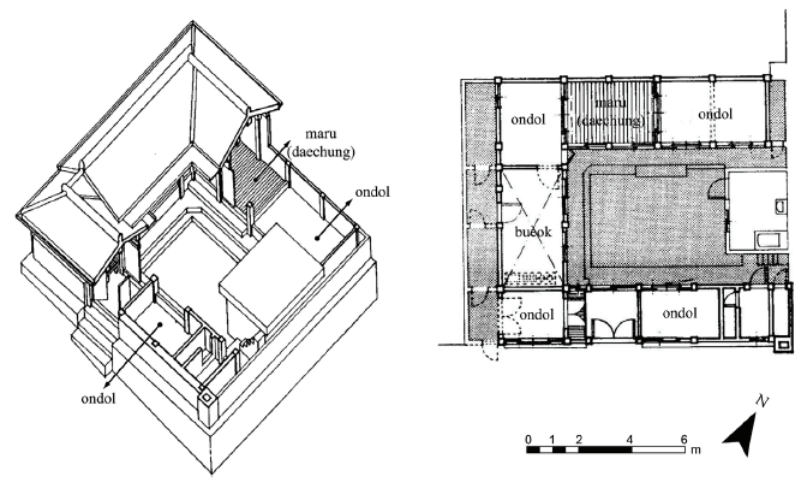

Figure 7. Typical urban hanok constructed between the 1930s and the 1960s in Seoul (source: Kwon et al., 2014)

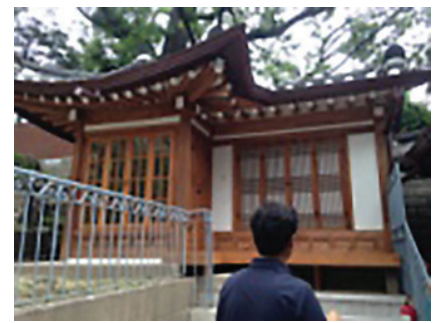

Figure 8. Traditional Korean house called hanok in Seochon (source: observation, 2016)

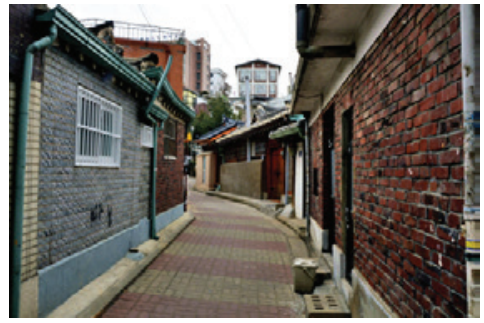

Figure 9. An alleyway in Ogin-dong, Jongno-gu, Seochon (source: Korea times photo by Yun Suh-young, 2014) chants. Seochon is a town where a large number of the middle class people used to live. Some were artists and artisans, mostly skillful people -who were somewhere between the yangban (gentry) class and commoners. The people here were dynamic and their life story can be seen on stones because artists would carve them into artworks (TheKoreatimes, 2015).

Seoul Metropolitan Government issued a preservation plan and composed a team of architects and academics to observe and investigate the condition of Seochon and any possibilities for the preservation there. As the result of this action, it turns out that Seochon has great potential for preservation (Lim, 2012).

Seochon village is a $583.000 \mathrm{~m}^{2}$ neighbourhood area. At this place, hanoks can be found everywhere. The distribution of hanok in Seochon can be seen in Figure 10. Hanoks spread throughout Seoul, and a few of hanoks are spread across three main gates namely Heunginjimun, Sukjeongmun and Sungnyemun. In this area, it is not generally allowed to knock the hanoks down, and the developers must obtain a special permission to build a building on this area. One of the causes of the decreasing number of hanoks is the growth of apartments and modern buildings occurred since the 1960s because the government pursued the development of multi-unit residential houses to solve the problem of slums. Many buildings in Seochon are old. For example, the oldest one dates back to the year of 1910 (Japanese rule period). Buildings constructed between

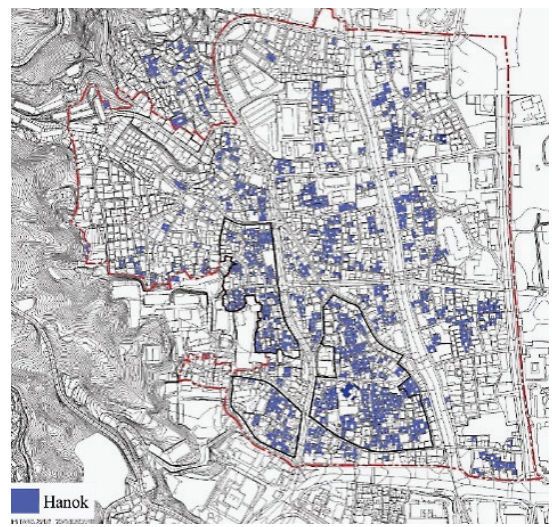

Figure 10. The distribution of hanokin Seochon village (source: Seochon district plan, 2010) 


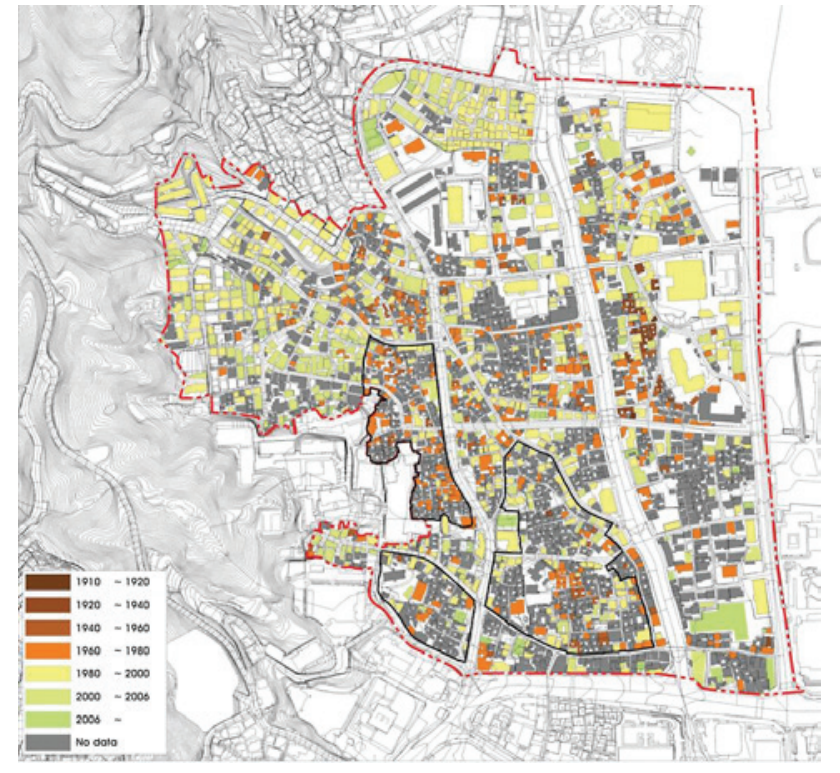

Figure 11. Construction Year of Buildings (source: Final Report for Seochon district plan, 2010)

1910 and 1920 are marked with a very dark brown color, and most of them are located in Changseong-dong in the Middle West side of Seochon. Buildings constructed between 1920 and 1960 are marked with two different shades of brown, and are sparsely located all over Seochon. Almost all neighborhoods have buildings built in this era. More recent buildings constructed between 1960 and 1980 are marked with orange color, and many buildings are hanoks, mostly them which are located in the central part of Seochon (Lim, 2012).

Here, new and modern buildings are marked with either yellow (1980-2000), pale green (2000-2006), or lime green (>2006) (Kwon et al., 2014; Lim, 2012). Office buildings are mostly built in the yellow area. Newer houses and multiunit buildings are sprawled in pale green or lime green. These three colors are very dominant in Okin-dong as it is one of the most developed neighborhoods in Seochon.

Unfortunately, some hanoks are unidentified in terms of the year of construction. For instance, the buildings with grey color do not have exact time record. Some buildings besides hanoks, including Tongin Market, is one of Seoul's most prominent traditional markets (Lim, 2012). The construction year of building can be seen on Figure 11.

\section{Discussion}

\section{Normative Aspects}

The Indonesian Government give the great attention to the preservation of the assets with high historical values, and it has been legislated on the law 26/2007 which states about the importance of socio-cultural aspects in the implementation of spatial planning. The spatial planning has to accommodate the social and cultural values and heritage assets. In the law No. 11/2010, the govern- ment set about heritage, cultural structure, cultural heritage sites, and the area of cultural heritage that needs to be conserved. According to the provision No. 73, zoning system includes cultural heritage consists of a core zone, a buffer zone, a development zone, and a supporting zone. Furthermore, there is also provision No. 80 that regulates the revitalization of cultural heritage sites and the cultural heritages area concerning spatial, layout, social function and original cultural landscape.

Based on the law No 11 year 2010, Kauman is classified as a cultural heritage area. This can be seen from the characteristics below: 1) contains two or more cultural heritages; 2) can be categorized as cultural heritage objects when they are 50 years old or more, represent the antique 50 years or more; 3 ) have a special meaning of history and science; 4) and have the cultural values that can strengthen the nation. Some old buildings found in Kauman consist of vernacular traditional style, indishce, jengki, art deco, and modern. The age of the buildings is approximately 50 to 150 years. The condition of these buildings is not well-maintained, and many of them have been broken down and were replaced with new buildings. According to the Regulation No. 14 year 2011 issued by the municipality of Semarang regarding City Spatial Plan, Kauman is included in zone-1, which is part of the old town of Semarang. Furthermore, according to the Regulation No. 69 , Kauman is included as a cultural heritage area along with several historic heritage sites in Semarang. Management plans are intended to include: (1) the preservation of social and cultural patterns, (2) the rules related to the changes of the size and shape of the building, and (3) the development of tourism. However, in its implementation, this regulation has not effectively done yet. Based on the observations, Kauman has suffered a depreciation of ancient buildings number within the last 20 years in which around 50 ancient houses has been lost and replaced by modern buildings. According to Wijanarka (2007), it was caused by the malfunction of old building to accommodate the changing needs of people and the boredom of people against old building. Moreover, they want the new one (Wijanarka, 2007). The external factors were caused by the development of modern projects in downtown such as super markets, hotels, rental offices, etc. Meanwhile in Seoul the number of hanoks decreased approximately from 130.000 in the early 1960 s to 24.000 in the early 2000s (Kwon et al., 2014). According to Kwon et al. (2014), the loss of hanoks in 2000-2013 are influenced by factors of parcels, neighborhoods, and urban scale such kind of internally connected urban environmental, development of modern facilities in the city centre.

\section{City planning aspects}

Kauman area is both included in the old town area and in the main trade zone of Semarang. Generally, the government town plan supervise the development in Kauman, according to the Spatial Plan of the City applied from 2011 until 2031 (Regulation No. 14 year 2011) and Detail Spa- 
tial Plan of the City. However, so far, there have been no significant plans related to the development of Kauman.

The preservation of Seochon village was started in 2000, by issuing the policy on Seoul's first planning of inner-city area for historic preservation. Subsequently in 2006, the municipality of Seoul undertook the preparation of citywide investigation of hanoks, the special investigation to assess hanoks buildings conducted by the Seoul Institute. Furthermore in 2008, the Seoul city government made a policy called Cancellation of Chebu Housing Redevelopment Plan because this redevelopment would threaten the existence of hanoks. In 2010, the government drafted Announcement of Neighbourhood Planning Unit. Furthermore in 2014 they also issued the Basic Plan for management of historical area. Based on the dialogue, regulations are also needed for the construction of the area around the location of objects because the control of development around the object is as important as the object of control in the region itself. Over the years, since the start of Seochon's preservation project, the government has been trying to buy lands or private hanok houses from the citizens in order to save them from extreme change. Some of the efforts have been successful, and these hanok houses were then transformed into galleries or display of traditional houses. The private parties who own a hanok in Seochon need to understand the historical significance of the built environment and work alongside the government to conserve Seochon in general and their own houses in particular (Lim, 2012). In 2008, the Seoul Metropolitan Government invested 370 billion won, or 323 million USD to preserve the hanoks. The government also provided some 100 million won, or 873.000 USD per home in the form of loans or subsidies for hanok preservation. The Government also purchased 33 hanoks to be used as a museum or an exhibition space. In Seochon, there are approximately 2.199 buildings; where $68.9 \%$ is residential, $40 \%$ of them are wooden structure, and about 670 buildings are hanoks. It is very important to motivate people to aware of the importance of preservation. Learn from the case of Seochon, in which the Seoul municipality alocated much incentives of funding and the preser-

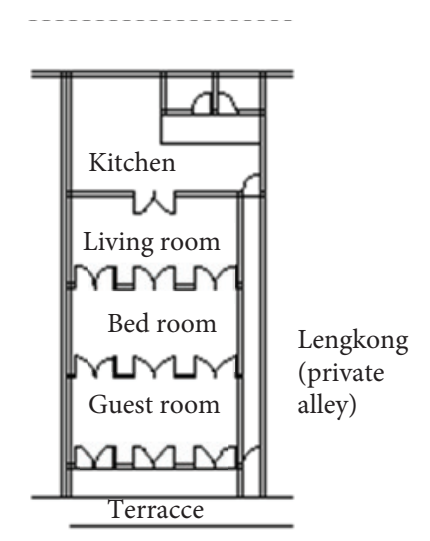

Figure 12. Ground plan of omah a vernakular javanese house in Kauman (source: Suprapti et al., 2017) vation, maintenance and rebuilding of traditional houses, and they also prepared constructors and the consultants to carry out these duty.

\section{Comparation between Hanok and Omah}

Both of hanok \& omah have a clear responses to the local climates, hanok adapts the four seasons, while omah adapts the two seasons of tropical climate. Hanok have two contrasted structural floors namely ondol (heated floor), and maru, which is wood-floored hall with an empty space beneath for ventilation (Choi et al., 2013), see Figures 7 \& 8; Omah response tropical climate through ordering few elements: (1) the air cushion located between roof and ceiling controlling the air inside house from above side, (2) the terrace located in the front of house controlling the air inside house from front side, (3) the dominant opening doors and windows in front, side and back facade of house to allow cross ventilation, (4) the private alleys along side of house (lengkong) allows a cross ventilation, see Figures $12 \& 13$; Regarding the ground plan hanok is simple and inward oriented compared to omah that is simple and outward oriented with more flexible plan arrangement for changing. From the social cohesion, Kauman has enough strong since they have been a tight relationship of kinship, while Seochon is heterogenic community; In relation with symbolism Kauman is symbol of egalitarian-religious and openness society, in the other hand Seochon is symbol of middle class who has intellectualist and artist lifestyle, which is rather limited in their social life.

\section{Public Participation}

Public participation is an important aspect of the realization of preservation efforts. Together with the government, public should support the preservation especially in private buildings. Participation is defined as a tool that is interpreted as an active community involvements in the whole process of activities as a growth cohesiveness between communities, and community and government. Community participation means the existence of a whole society and the awareness of community has increased along with the increasing awareness of citizens' rights and

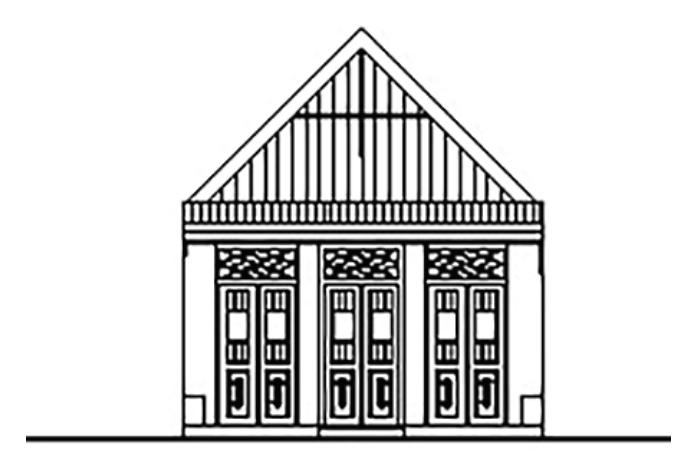

Figure 13. Dominant doors in the fasade of Omah (source: observation, 2016) 
obligation. Community participation in one of priorities which should be achieved in preservation measures (Rypkema, 2005). In Kauman, the formation of social participation appears in the form of implementation through community participation in social activities undertaken by the community. Kauman people seem excited and enthusiastic in participating social and religious activities in Kauman. Citizens are also eager to donated materials like land, money, or others to religious educational institutions in Kauman. According to their view, charity is a perpetual charity which the reward will continue to flow to the donors for building the results of earlier participation utilized for the benefit of the activities of Muslims in general (Suprapti et al., 2017). Kauman residents are very familiar with the activities of social participation. The social cohesion is still strong, because the system of kinship among them is still strong. Kauman residents also like to participate materially, considering most of are trades and relatives of Kyai. Both of these backgrounds are the causes that drive them to participate in relating the Islamic activity (Sandri \& Wahyono, 2013). Public participation in Seochon has done together by all stakeholders: community, experts, academics, investors, and governments which have concerned in preservation. One of an architect named Minsoo Jang. He was an architect in a consultant. In the last few years, he has done a research in Seochon. $\mathrm{He}$ accompanied community to take care the hanoks. He also motivated them to participate in conducting preservation of hanoks. Community in Seochon have realized the importance in conducting preservation of hanoks which is strengthen genuine culture identity and make it to be an attraction for tourism. With that way community have got the benefit of income.

\section{Conclusion and recomendation}

Kauman is a cultural heritage that becomes the witness of the foundation of historical spaces and buildings, traditions and social life which contribute significant meaning not only in its own area but also in Semarang. Historical Building and space like Masjid Agung is still wellmaintained, but the problems are that there were additional new modern buildings around its area that did not have similar context to the genuine building. Residential buildings performance have various architectural styles: Javanese vernacular house (omah), Indische, Art Deco, Jengki, as well as modern style, having age from 50 to 150 years old, which are still well-maintained, moderate but look awful. There are also some local culture and Muslim social life. The governmental law that aims to preserve the regional historical heritages is still have a weakness. Seochon has experienced a significant dynamic social life which makes this village different from other villages in Seoul. The government made a policy to preserve this village in 1990 in order to make it as a tourism destination that displays some attractive features like hanoks and the social life of its people completed with its facilities such as home stays, museums, galleries, cafes, book stores, tra- ditional markets, and traditional cuisines. This success is due to the good collaboration among the Government, experts from various fields, scholars, investors and also the community.

Learning from Seochon village, in relation with Kauman, there are some important things that must be considered, such as the readiness of legal instruments and law enforcers. The law is associated with the preservation and conservation the regions and its development plan. There should also be regulations in the management, finance, and technical implementation. Besides, it is also necessary that the regulations cover the Kauman and its surrounding. In the level of Kauman needs a policy to investigate the potential and the problems in the field. Having known the potential and the problems directly required an appropriate regulation of management, to preserve Kauman by synergizing various existing sources both materially and immaterial for optimal results. Systematically, cooperations among government, communities, experts, investors needed concern to the preservation of building and environment. Incentives and disincentives should be given to the public, so they will motivate people to be more aware about preservation and preservation for the sustainability of their social and cultural life and their future generations in particular and for the city in general.

Hanok's survival today, due to the government's massive policies related of preservation \& conservation.

Omah's survival today, due to the demands of low income inhabitant need, but not yet accompanied by implemented preservation and conservation policy able to be implemented.

\section{Acknowledgments}

Researchers would like to express a gratitude to the students of bachelor degree of Architecture Engineering, Diponegoro University, as well as students of Graduate School of Environmental Studies Seoul National University, who have been involved in this research. Especially for Mr. Minsoo Jang who has guided for the observation in Seochon Seoul. Also many thanks to the Faculty of Engineering, Diponegoro University for funding this research.

\section{References}

Beal, G. (2013). Island style: tropical dream houses in Indonesia. Tuttle Publishing.

Choi, J. S., Chun, J. H., Hong, H. O., Kang, S. J., Kim, D. N., Min, C. H., Oh, H. K., \& Park, Y. S. (2013). Hanoak traditional Korean homes. Seoul, Hollym.

Final Report for Seochon District Plan. (2010).

Hanru, H. (2012). Reinventing the Social. Exhibitionist, 6 (Juni 2012), 45-49.

Jeon, B., \& Kwon, Y. (2012). Hanok and the history of the Korean house. Seoul: Dongnyok Publishers.

Kwon, Y., Kim, S., \& Jeon, B. (2014). Unravelling the factors determining the redevelopment of Seoul's historic hanoks. Habitat International, 41(January 2014), 280-289. Elsevier, Science Direct. https://doi.org/10.1016/j.habitatint.2013.09.003 
Leushuis, E. (2014). Exploration guides of heritage cities in Indonesia. Publisher: Ombak, Yogjakarta.

Lim, H. (2012). Future development directions through the evaluation of the policies in Seochon, Seoul. The Seoul Institute: Seoul.

Muhadjirin, N. (2007). Scientific methodology paradigm of qualitative, quantitative, and mixed. Publisher of Rake Sarasin, Yogjakarta.

Rypkema, D. D. (2005). Globalization, urban heritage, and the 21th century economy. Global Urban Development, 1 (issue 1 May 2005).

Sandri, D., \& Wahyono, H. (2013). Islamic activities in the village of Kauman Semarang. Journal of Teknik PWK, 2(3).

Santoso, J. (2013). Understanding urban transformation in Asia: case study of Jakarta. Journal of Tata Loka, 15(2).

Suprapti, A., Kistanto, H. N., Pandelaki, E. E., Indrosaptono, D. (2017). Control of spatial protection in Kampung Kauman Semarang. Journal of Architecture and Urbanism, 41(4). Routledge. https://doi.org/10.3846/20297955.2017.1402717
Suprapti, A., Budihardjo, E., Kistanto, H. K., \& Tungka, A. E. (2010). Ethnography-architecture in Kampung Kauman Semarang, a comprehension of cultural toward space. American Journal of Engineering and Applied Sciences, 3(3), 576-587. New York, Science Publication. https://doi.org/10.3844/ajeassp.2010.576.587

Suprapti, A. (2016). Concept of self conservation in a traditional village: an empirical study of Kampong Kauman Indonesia. International Transaction Journal of Engineering, Management, Applied Sciences and Technologies, 7(1). Tuengr Group.

TheKoreatimes. (2015). Retrieved from http://www.koreatimes. co.kr/www/news/culture/2015/02/617_153323.html

Wijanarka. (2007). Semarang past; theory \& design of historic area. Publisher Ombak, Yogjakarta.

Wirastari, A. V., \& Suprihardjo, R. (2012). Preservation of cultural heritage area based on public participation (case study: cultural heritage area of Bubutan Surabaya). Journal of TEKNIK ITS, $1(1)$. 